\title{
Pembuatan Alat Tracking Artefak pada Museum Menggunakan Modul GSM Berbasis Mikrokontroler dan Short Massage System.
}

\author{
Irzan Marza S \\ Sistem Komputer Fakultas Teknologi Informasi Universitas Andalas Jl. Universitas Andalas, Limau Manis, Pauh, Kota Padang, Sumatera Barat
}

\section{ARTICLE INFORMATION}

Received: January 8, 2019

Revised: February 20, 2019

Available online: March 29, 2019

\section{KEYWORDS}

Modul GSM, Triangulasi, Arduino ATMega.

\section{CORRESPONDENCE}

E-mail: zanmarza3@ gmail.com

\section{A $\quad$ B $\quad S$ T $\mathbf{R}$ A $\mathbf{C}$ T}

The museum is in charge of providing facilities for these research activities for anyone, in addition to the museum in charge of carrying out the research activities themselves and disseminating the results of the research to the development of general science. However, in reality there is still the fact that cases of missing historical objects have a value of up to millions of rupiahs. This study aims to create a tracking system that is able to track artifacts in the museum using the BTS system. Therefore, the author will make a tool that can track the position of the artifact with the Tracking method. The design of the study that the author will adopt from the above problem is "Making an Artifact Tracking Tool at the Museum Using a Microcontroller and Short Massage System-Based GSM Module".

\section{PENDAHULUAN}

Museum merupakan suatu lembaga yang memiliki fungsi selaku tempat penyimpanan, perawatan, pengamanan dan pemanfaatan benda-benda bukti materil hasil budaya manusia yang hendaknya nanti akan menjadi penunjang bagi penelitian dan ilmu pengetahuan di masa mendatang[1]. Museum juga memiliki peran sebagai edukasi bagi masyarakat tentang peninggalan benda-benda prasejarah. Selain itu museum bertugas menyediakan sarana untuk kegiatan penelitian tersebut bagi siapapun, di samping museum bertugas melaksanakan kegiatan penelitian itu sendiri dan menyebar luaskan hasil penelitian tersebut untuk pengembangan ilmu pengetahuan umumnya [2]. Untuk penanganan objek museum yang baru diperoleh, akan dicatat terlebih dahulu dalam buku register oleh seorang registrar. Setelah itu dengan disertai keterangan yang lengkap dikirim ke laboratoarium untuk diperiksa, atau dibentuk suatu tim pengadaan yang berperan dalam penilaian dan penyeleksian objek yang ditawarkan. Dari laboratoarium atau tim pengadaan benda tersebut dibawa kembali ke bagian registrasi. Objek yang disetujui sebagai koleksi museum ditempatkan sementara digudang, di dalam rak-rak bagian keilmuan masing-masing, untuk menunggu giliran dikirim ke laboratorium kembali atau ke bagian restorasi jika benda itu rusak. Jika benda itu dalam kondisi baik hanya dibersihkan dari kotoran atau debu saja, dakemudian diserahkan kepada kurator yang bersangkutan [3]. Namun, pada kenyataannya masih ditemukan fakta bahwa kasus-kasus kehilangan benda-benda bersejarah yang mempunyai nilai harga hingga jutaan rupiah. Hal tersebut tentunya sangatlah disayangkan dimana museum yang diharapkan merupakan tempat penyimpanan dan perawatan barang bersejarah malah menjadi tempat yang rentan untuk dijarah oleh pihak yang ingin mendapatkan untung secara pribadi.

Maka dari itu, paper ini akan membuat suatu alat yang dapat melacak posisi artefak tersebut dengan metode Tracking. Rancangan penelitian yang akan paper ini angkat dari masalah diatas yaitu pembuatan alat tracking artefak pada museum menggunakan modul GSM berbasis mikrokontroler dan short Messaging System. Dengan adanya rancangan ini diharapkan nantinya memudahkan pihak kurator untuk melacak posisi dari artefak berharga museum dan tingkat keamanan terhadap bendabenda museum akan jauh lebih baik. 


\section{LANDASAN TEORI}

\section{A. Museum}

Museum merupakan suatu lembaga yang memiliki fungsi selaku tempat penyimpanan, perawatan, pengamanan dan pemanfaatan benda-benda bukti materil hasil budaya manusia yang hendaknya nanti akan menjadi penunjang bagi penelitian dan ilmu pengetahuan di masa mendatang[1]. Pengadaan merupakan suatu kegiatan pengumpulan berbagai benda yang akan dijadikan koleksi museum, baik berupa benda asli (realia) ataupun tidak asli (replika). Pengadaan koleksi dapat dilakukan dengan cara: (1) Hibah (hadiah atau sumbangan); (2) Titipan; (3) Pinjaman; (4) Tukar menukar dengan museum lain; (5) Hasil temuan (dari hasil survei, ekskavasi, atau sitaan); dan (6) Imbalan jasa (pembelian dari hasil penemuan atau warisan) [3].

\section{B. Base Tranceiver Station (BTS)}

BTS merupakan komponen jaringan yang menghubungkan antara pengguna perangkat komunikasi dengan jaringan. Yang dimaksudkan dengan perangkat yaitu telpon, komputer dan konektivitas internet nirkabel. Sedangkan yang dimaksud jaringan yaitu seperti GSM, CDMA, WiFi, WAN dan lainya. Pada umumnya yang biasa digunakan yaitu teknologi komunikasi GSM dan CDMA. Namun ada juga yang menyebutnya dengan RBS (RadioBase Station), node B (3G Network), BS (base station [4].

BTS dapat dioperasikan pada frekuensi $900 \mathrm{MHz}$ dengan panjang gelombang $30 \mathrm{~cm}$. Kualitas sinyal dipengaruhi oleh keragaman jarak antar dua buah menara dan keragaman ruang. Biasanya BTS akan memiliki beberapa transceiver (TRXs) yang memungkinkan untuk melayani beberapa frekuensi yang berbeda dan berbagai sektor sel (dalam kasus BTS sectorised). Sebuah BTS dikendalikan oleh kontroler utama base station melalui fungsi base station kontrol (BSC). BSC ini dilaksanakan sebagai unit diskrit atau bahkan tergabung dalam TRX di BTS kompak. Para BSC menyediakan operasi dan pemeliharaan ( $\mathrm{O} \& \mathrm{M})$ koneksi dengan Network Monitoring System (NMS), dan mengelola kondisi operasi dari TRX masing-masing, serta penanganan perangkat lunak dan koleksi alarm. Struktur dasar dan fungsi dari BTS tetap sama tanpa teknologi nirkabel [4].

\section{Triangulasi BTS}

Sistem BTS telah terbukti untuk dapat melacak lokasi suatu benda [5]. Prinsip dasar sistem tracking ini mirip dengan sistem tracking berbasis kekuatan sinyal yang diterima (RSSI) [6]. Pada dasarnya setiap SIM memiliki Cell ID (CID) yang berbeda-beda dan berubah-ubah tergantung dari kekuatan sinyal dari BTS. Dan setiap BTS tersebar dalam wilayah tertentu dan mempunyai nomor urut. Nomor urut BTS ini kemudian diberikan ID yang disebut Local Area Code (LAC). LAC juga biasa berubah-ubah dan berbeda-beda tergantung dengan jarak SIM dengan BTS. Pada CID terdapat koordinat data dari SIM, sedangkan pada LAC terdapat data koordinat dari BTS [7].

Dengan diketahui bahwa SIM memiliki CID yang berbeda-beda dan berubah-ubah maka maka kita dapat mendapatkan lokasi SIM dengan menggunakan triangulasi BTS [7].

Triangulation Proses positioning berbasis Cell ID melibatkan perhitungan triangulasi. Trangulasi adalah sebuah metode yang dapat digunakan untuk menentukan posisi dari suatu perangkat dengan menggunakan perhitungan dari tiga buah (BTS) yang paling dekat dengan perangkat yang akan dilacak. Metode ini dapat dilakukan jika perangkat tersebut tersambung dengan BTS atau sedang melakukan komunikasi [7].

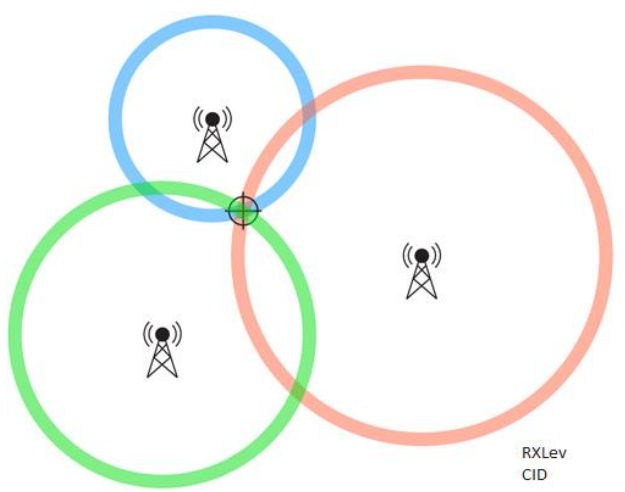

\section{Gambar 1 Menetukan Titik Koordinat Alat Dengan Triangulasi [8]}

Metode triangulasi memanfaatkan penghitungan nilai kuat sinyal serta latittude dan longitude dari masing-masing BTS yang paling dekat dengan perangkat. Koordinat latitude dan longitude masing-masing BTS, misal (x1, y1), (x2, y2), dan (x3, y3), akan dihitung untuk menentukan titik tengah dari koordinat masing BTS tersebut dengan persamaan berikut [9].

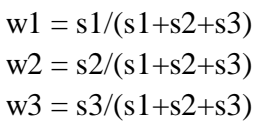

dengan:

$\mathrm{w}_{\mathrm{n}}$ : bobot sinyal

$\mathrm{s}_{\mathrm{n}}$ : kuat sinyal

lalu untuk mendapatkan posisi dari alat, nilai dari bobot sinyal yang didapatkan dimasukan kedalam persamaan berikut

$\mathrm{x}=(\mathrm{w} 1 * \mathrm{tx} 1+\mathrm{w} 2 * \mathrm{tx} 2+\mathrm{w} 3 * \mathrm{tx} 3)$

$\mathrm{y}=(\mathrm{w} 1 * \mathrm{ty} 1+\mathrm{w} 2 * \mathrm{ty} 2+\mathrm{w} 3 * \mathrm{ty} 3)$ 
dengan:

$\mathrm{x}$ : latitude alat

y : longitude alat

$\mathrm{tx}_{\mathrm{n}}$ : latitude tower BTS

$\mathrm{ty}_{\mathrm{n}}$ : longitude tower BTS

\section{Modul GSM SIM 800L}

Modul GSM SIM 800L, seperti terlihat pada gambar 2 merupakan modul GSM yang paling popular dan mudah digunakan untuk melakukan berbagai keperluan pengendalian jarak jauh via handphone. Untuk saat ini terdapat beberapa tipe dari Breakout Board, tetapi yang paling banyak dijual di Indonesia yaitu versi mini dengan kartu GSM jenis Micro SIM [10].

\section{E. ATMEGA 2560 (Arduino Mega ADK)}

Arduino MEGA ADK adalah board mikrokontroler berdasarkan ATmega2560. memiliki antarmuka host USB untuk terhubung dengan ponsel berbasis Android, berdasarkan IC MAX3421e. Memiliki 54 pin input / output digital (15 dapat digunakan sebagai output PWM), 16 input analog, 4 UART (port serial perangkat keras), osilator kristal $16 \mathrm{MHz}$, koneksi USB, colokan listrik, header ICSP, dan tombol reset.MEGA ADK didasarkan pada Mega 2560. Mirip dengan Mega 2560 dan Mega, fitur ATmega8U2 diprogram sebagai konverter USB-to-serial. Arduino MEGA telah banyak digunakan pada sistem-sistem IoT dalam berbagai topik [11-13].

\section{METODOLOGI PENELITIAN}

\section{A. Jenis dan Metodoogi Penelitian}

Jenis penelitian yang digunakan dalam penulisan paper ini adalah penelitian eksperimental. Penelitian eksperimental adalah jenis penelitian yang digunakan untuk melihat hubungan sebab akibat. Penelitian eksperimental digunakan untuk mencari pengaruh perlakuan terhadap yang lain dalam kondisi yang terkendali, proses penelitianpun dilakukan secara sistematis, logis dan teliti didalam melakukan kontrol terhadap kondisi.

Adapun tahap-tahap yang dilakukan dalam penelitian ini akan ditunjukan pada gambar 2 .

\section{B. Perancangan Umum Sistem}

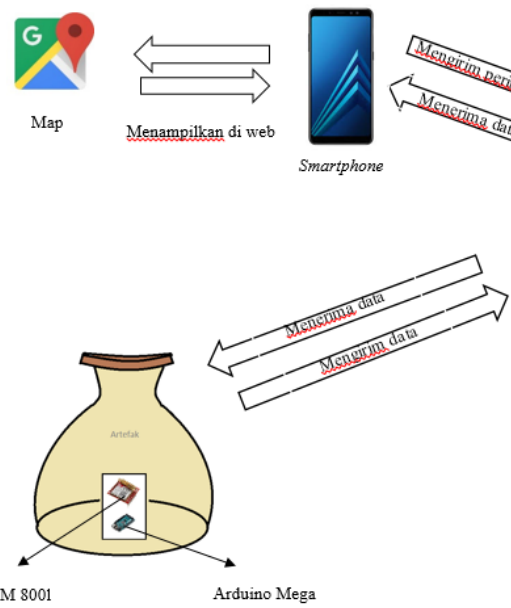

\section{Gambar 2 Rancangan Umum Sistem}

Berdasarkan gambar di atas, rancangan umum sistem adalah kurator bisa mengirimkan SMS berupa permintaan lokasi artefak yang ingin dilacak. Kode permintaan lokasi nantinya akan diinisialisasikan pada program kendali Arduino. Modul GSM SIM 8001 yang diletakan bersama Arduino didalam sebuah wadah kotak akan menerima pesan dan mengirimkan sinyal ke BTS. Wadah kotak tersebut akan di bentuk seminimal mungkin agar dapat mudah di sembunyikan atau ditempel pada artefak nantinya. Pada saat posisi telah didapatkan, maka kurator dapat melihat posisi di google map dengan membuka link yang dikirimkan melalui SMS.

\section{Rancangan Proses}

Secara sistematis, alur fungsi sistem secara keseluruhan dapat dilihat pada diagram alir berikut ini : 


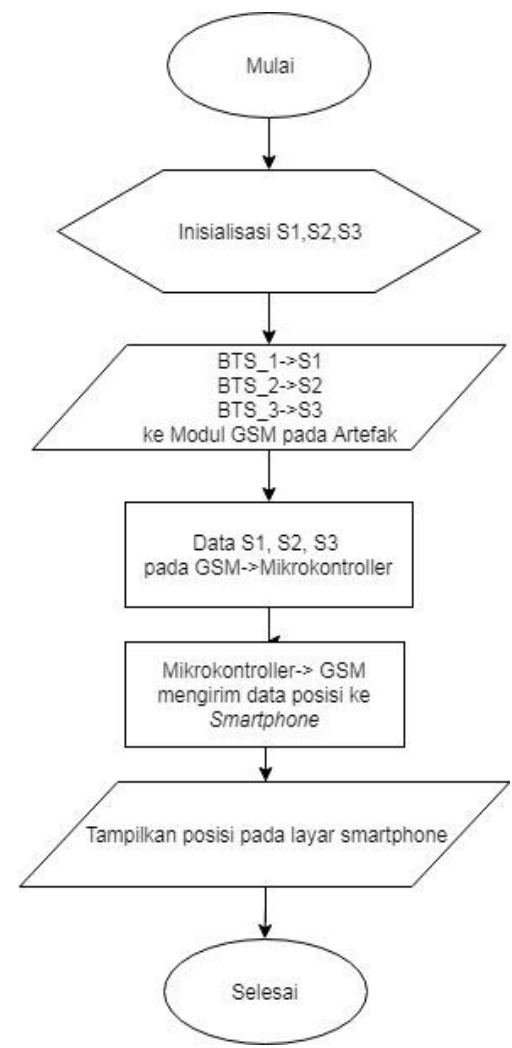

Gambar 3 Diagram Alir Proses

Berdasarkan diagram di atas, inisialisai S1, S2, dan S3 merupakan kuat sinyal yang dihasilkan oleh BTS 1, BTS 2, BTS 3 secara berurutan. Dan apabila data diterima, maka modul GSM SIM 8001 akan mencari data BTS. Lalu data yang diterima di hitung dalam program dan akan dikirimkan kembali ke smartphone berupa SMS dengan link yang akan terhubung ke google map.

\section{C.1 Perancangan Perangkat Keras}

Bentuk perancangan hardware dari sistem ini adalah sebagai berikut :

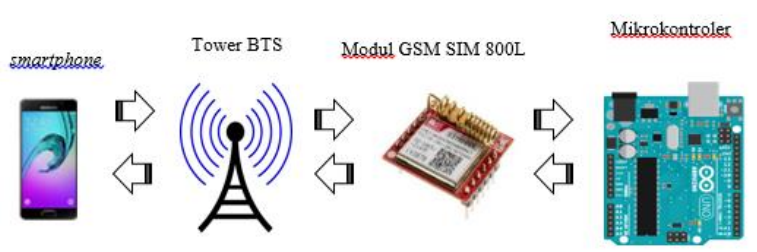

\section{Gambar 4 Perancangan Perangkat Keras}

Berdasarkan gambar perancangan hardware di atas, prinsip kerja dari sistem ini adalah :

1. Smartphone digunakan untuk mengirimkan pesan SMS berupa permintaan posisi.
2. Tower BTS akan menerima sinyal dan melanjutkan pesan untuk dikirim ke modul GSM SIM 8001.

3. Modul GSM SIM8001 akan menerima pesan dan posisi akan ditentukan oleh BTS dengan triangulasi.

4. Mikrokontroller melakukan parsing data oleh server yang nantinya dapat dikirimkan kembali oleh modul GSM SIM8001 ke smartphone.

\section{C.2 Perancangan Perangkat Lunak}

Pada perancangan perangkat lunak dilakukan perancangan program dengan menggunakan Arduino IDE. Arduino IDE digunakan untuk membandingkan data yang dibaca dengan data yang ada. Secara sistematis, cara kerja software kendali ini dapat dilihat pada diagram alir berikut :

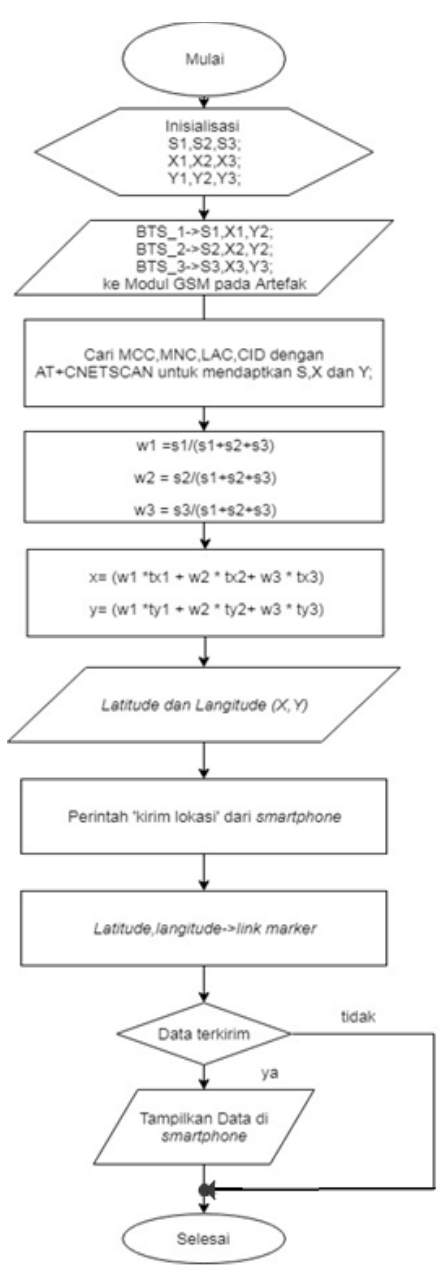

Gambar 5 : Diagram alir Perangkat Lunak Sistem Kendali Arduino pada Mikrokontroler

Berdasarkan diagram alir di atas dapat dijelaskan, bahwa kita butuh menginisialisasikan $\mathrm{S}, \mathrm{X}, \mathrm{Y}$ sebagai kuat sinyal,latitude dan langitude secara berurutan untuk mendapatkan bobot sinyal yang dinisialisasikan sebagai W. lalu dari data tersebut akan diproses dengan menggunakan rumus triangulasi. Hasil dari penghitungan 
tersebut akan didapatkan data latitude dan longitude. Data latitude dan longitude tersebut akan ditambahkan sisipan link yang nantinya akan dikirimkan ke-smarphone melalui SMS.

\section{HASIL DAN ANALISA}

\section{A. Implementasi Perangkat Keras}

Pembuatan alat tracking artefak pada museum menggunakan modul gsm berbasis mikrokontroler dan short massage system ini menggunakan modul GSM SIM 8001 yang berfungsi mencari data tower BTS dan pengiriman SMS yang terintegrasi dengan mikrokontroller Arduino Mega ADK sebagai pengontrol dari sistem.

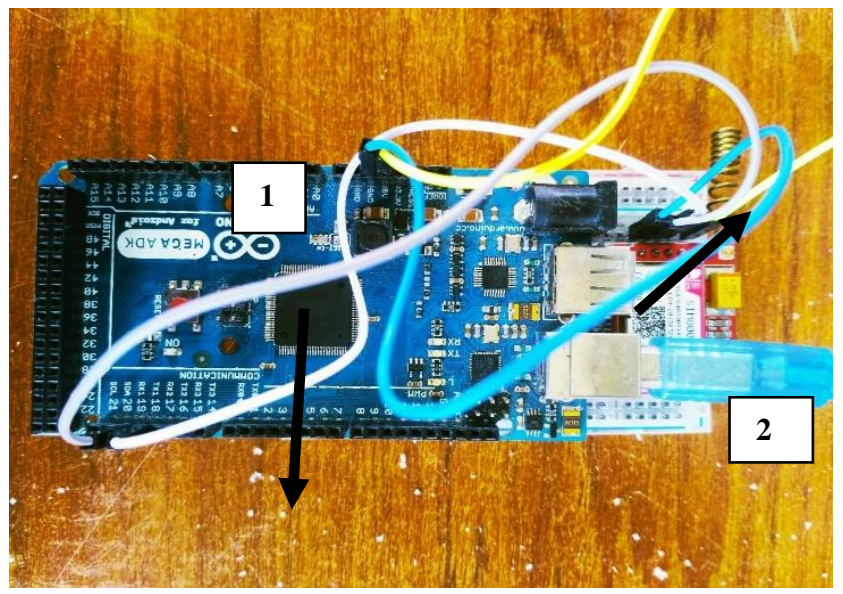

Gambar 6 Perangkat Keras Tampak dari Luar

Pada Gambar 6 dapat dijelaskan bahwa:

1. Mikrokontroler Arduino Mega ADK yang berfungsi sebagai pengontrol kinerja sistem pada alat.

2. Moudul GSM SIM 8001 yang berfungsi untuk mencari data tower terdekat dan mengirimkan SMS ke pada pengguna smartphone.

\section{B. Implementasi Perangkat Lunak}

Perangkat lunak yang digunakan pada Alat Mobile Tracking Artefak pada Museum Menggunakan Modul GSM Berbasis Mikrokontroler yaitu Arduino IDE. Program yang tertanam pada sistem dibuat dengan menggunakan bahasa pemrograman $\mathrm{C}$.

Modul GSM akan diperintahkan oleh mikrokontroler melalui ATcommand untuk meminta data dari BTS terdekat. Data BTS yang didapatkan akan diolah oleh mikrokontroler melalui Arduino IDE. Didalam Arduino IDE tersebut akan dimasukan program yang menghitung posisi alat berdasarkan kuat latitude, longitude dan kuat sinyal yang didapatkan dari BTS.

\section{Implementasi Keseluruhan Sistem}

Pengujian dan analisa sistem secara keseluruhan pada pembuatan alat tracking artefak pada museum menggunakan modul gsm berbasis mikrokontroler dan short massage system dilakukan dengan cara mengaktifkan seluruh sistem dan menempatkan sistem pada suatu tempat tertentu disekitaran area Universitas Andalas. Sistem dapat melakukan pencarian lokasi menggunakan modul GSM SIM8001 tanpa harus menggunakan modul Global Positioning System (GPS). Saat menggunakan "AT+CNETSCAN" kita bisa mendapatkan informasi tower yang berada di sekitar modul GSM SIM8001. Seperti yang terlihat di Gambar 4.9

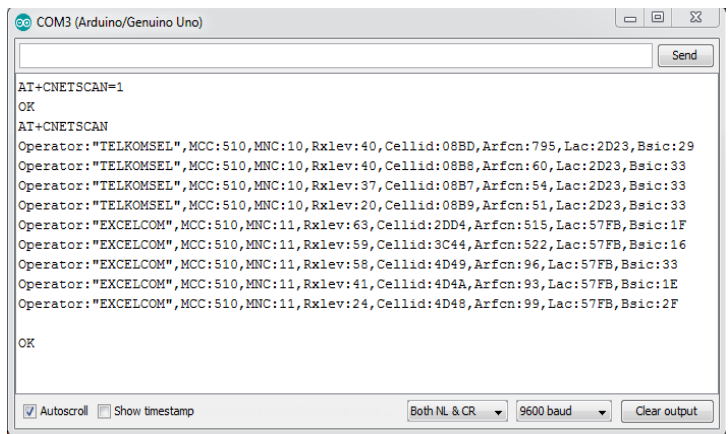

Gambar 7 Pencarian Info Tower di laboratorium Sinyal dan Sistem.

Keterangan :
MCC : Mobile country code
MNC : Mobile network code
Rxlev : Receive level
Cellid : Cell id
Arfen : Absolute radio frequency channel number
Lac : Location area code
Bsic : Base station identity code

Setelah mendapatkan nilai MCC, MNC, Cellid, dan Lac kita dapat mengetahui latitude dan langitude dari tower, dengan memasukan nilai tersebut ke CellID kita dapat mengetahui posisi tower, dimana CellID adalah situs yang dapat menampilkan lokasi tower berdasarkan data yang diberikan. Seperti yang terlihat pada Gambar 8.

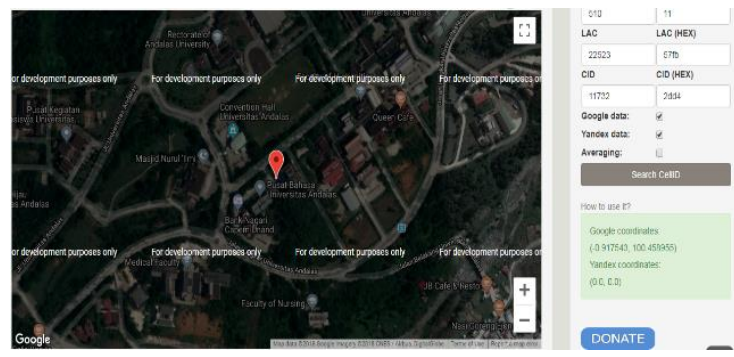

Gambar 8 Pencarian tower BTS EXELCOM (Cell id 2dd4) 
Setelah latitude dan longitude didapatkan, maka kita dapat mencari koordinat dari modul GSM dengan rumus triangulasi sebagai berikut :

Latitude $=($ Rasio1 $\times$ Latitude1 + Rasio2 $\times$ Latitude2 +

Rasio3 x Latitude3)

Longitude $=($ Rasio1 $\times$ Longitude $1+$ Rasio $2 \times$ Longitude 2

+ Rasio3 x Longitude3)

Dimana Rasio1 adalah rasio kuat sinyal BTS 1, Rasio2 adalah rasio kuat sinyal BTS 2 dan Rasio3 adalah rasio kuat sinyal BTS 3.

Rasio didapatkan dari rumus :

$$
\begin{aligned}
& \mathrm{W} 1=\mathrm{S} 1 /(\mathrm{S} 1+\mathrm{S} 2+\mathrm{S} 3) \\
& \mathrm{W} 2=\mathrm{S} 2 /(\mathrm{S} 1+\mathrm{S} 2+\mathrm{S} 3) \\
& \mathrm{W} 3=\mathrm{S} 3 /(\mathrm{S} 1+\mathrm{S} 2+\mathrm{S} 3) \\
& \text { Keterangan : } \\
& \mathrm{W} 1=\text { rasio kuat sinyal } 1 \\
& \mathrm{~W} 2=\text { rasio kuat sinyal } 2 \\
& \mathrm{~W} 3=\text { rasio kuat sinyal } 3 \\
& \mathrm{~S} 1=\text { kuat sinyal BTS } 1 \\
& \mathrm{~S} 2=\text { kuat sinyal BTS } 2 \\
& \mathrm{~S} 3=\text { kuat sinyal BTS } 3
\end{aligned}
$$

\begin{tabular}{|c|c|c|c|c|}
\hline No & Tempat & $\begin{array}{l}\text { Koordinat Modul } \\
\text { GSM SIM8001 }\end{array}$ & $\begin{array}{l}\text { Koordinat pada } \\
\text { Google maps }\end{array}$ & $\begin{array}{l}\text { Selisih Jarak } \\
\text { (Meter) }\end{array}$ \\
\hline 1 & $\begin{array}{l}\text { Laboratorium } \\
\text { Sinyal dan } \\
\text { Sistem Siskom } \\
\text { UNAND }\end{array}$ & $\begin{array}{l}-0.920644, \\
100.456210\end{array}$ & $\begin{array}{l}-0.915377 \\
100.460975\end{array}$ & 513 \\
\hline 2 & $\begin{array}{l}\text { Lapangan FTI } \\
\text { UNAND }\end{array}$ & $\begin{array}{l}-0.918434, \\
100.458240\end{array}$ & \begin{tabular}{|l|}
-0.915443 \\
100.460943
\end{tabular} & 439 \\
\hline 3 & \begin{tabular}{|l} 
Teras \\
Auditorium \\
UNAND \\
(Tribun Timur)
\end{tabular} & $\begin{array}{l}-0.918331 \\
100.458490\end{array}$ & $\begin{array}{l}-0.914416, \\
100.459437\end{array}$ & 418 \\
\hline 4 & CH UNAND & $\begin{array}{l}-0.9199216 \\
100.4582357\end{array}$ & $\begin{array}{l}-0.916709 \\
100.457947\end{array}$ & 342 \\
\hline 5 & $\begin{array}{l}\text { Gedung } \\
\text { UNAND }\end{array}$ & $\begin{array}{l}-0.9183467 \\
100.4605873\end{array}$ & $\begin{array}{l}-0.922722 \\
100.448585\end{array}$ & 601 \\
\hline 6 & $\begin{array}{l}\text { Eakultas } \\
\text { Earmasi } \\
\text { UNAND }\end{array}$ & $\begin{array}{l}-0.926230 \\
100.433846\end{array}$ & $\begin{array}{l}-0.9183829 \\
100.4604707\end{array}$ & 427 \\
\hline 7 & $\begin{array}{l}\text { Perpustakaan } \\
\text { UNAND }\end{array}$ & $\begin{array}{l}-0.9159702 \\
100.4578394\end{array}$ & $\begin{array}{l}-0.918383 \\
100.460471\end{array}$ & 422 \\
\hline 8 & $\begin{array}{l}\text { Eakultas } \\
\text { Agribisnis }\end{array}$ & $\begin{array}{l}-0.9157671 \\
100.4592831\end{array}$ & $\begin{array}{l}-0.918383 \\
100.460471\end{array}$ & 485 \\
\hline 9 & RS UNAND & $\begin{array}{l}20661690.000000 \\
1588684000000 . .0\end{array}$ & $\begin{array}{l}-0.920533 \\
100.457230\end{array}$ & Error \\
\hline 10 & BC UNAND & $\begin{array}{l}-0.304859, \\
14751730000000 . . \\
.0\end{array}$ & $\begin{array}{l}-0.917032 \\
100.453513\end{array}$ & Error \\
\hline
\end{tabular}

Pada pengujian alat secara keseluruhan dilakukan 10 kali percobaan, dari percobaan tersebut terdapat 2 kali percobaan dengan keterangan tidak berhasil. Hal tersebut terjadi dikarenakan adanya error pada pengiriman data yang diambil pada tepi wilayah Universitas Andalas dan gedung-gedung yang mempengaruhi kekuatan sinyal dari BTS.

\section{Tabel 1 Pengujian Mencari Lokasi dengan}

\section{Triangulasi Menggunakan Modul GSM SIM8001}

Pada Tabel 4.4 dapat kita hitung persentase keberhasilan dengan rumus sebagai berikut:

$$
\begin{aligned}
& \text { Persentase Keberhasilan } \\
& =\frac{(\text { jumlah percobaan berhasil) }}{\text { (jumlah percobaan yang berh) }}
\end{aligned}
$$

Persentase Keberhasilan $=\frac{8}{10} \times 100 \%$

Persentase Keberhasilan $=80 \%$

Jadi, total persentase keberhasilan yang didapat adalah $80 \%$ dengan kegagalan $20 \%$.

Selisih jarak error rata-rata dapat dihitung dengan rumus berikut:

$$
\begin{aligned}
& \text { Selisih Jarak rata - rata } \\
& =\frac{(\text { jumlah selilsih jarak yang berhasil) }}{\text { (jumlah percobaan yang berhasil) }}
\end{aligned}
$$

Selisih Jarak rata - rata $=\frac{3647}{8}$

Selisih Jarak rata - rata $=455.87$

Jadi, selisih jarak rata-rata yang didapatkan adalah 455.87 meter Adapun bentuk hasil perhitungan secara manual adalah sebagai berikut :

$$
\begin{aligned}
\mathrm{W} 1 & =\mathrm{S} 1 /(\mathrm{S} 1+\mathrm{S} 2+\mathrm{S} 3) \\
& =46 /(46+33+29) \\
& =0.425925926 \\
\mathrm{~W} 2 & =\mathrm{S} 2 /(\mathrm{S} 1+\mathrm{S} 2+\mathrm{S} 3) \\
& =33 /(46+33+29) \\
& =0.305555556 \\
\mathrm{~W} 3 & =\mathrm{S} 3 /(\mathrm{S} 1+\mathrm{S} 2+\mathrm{S} 3) \\
& =33 /(46+33+29) \\
& =0.268518519
\end{aligned}
$$

Lalu mencari hasil dari persamaan diatas dimasukan kedalam persamaan berikut:

$$
\begin{aligned}
& X=\{(\mathrm{W} 1 \times \mathrm{Tx} 1)+(\mathrm{W} 2 \times \mathrm{Tx} 2)+(\mathrm{W} 3 \times \mathrm{Tx} 3)\} \\
&=\{(0.425925926 \times-0.923765)+(0.305555556 \times- \\
&0.914365)+(0.268518519 \times-0.920335)\} \\
&=(-0.393455463)+(-0.279389306)+(-0.27126991) \\
&=-0.91997176 \\
& \mathrm{Y}=\{(\mathrm{W} 1 \times \mathrm{Ty} 1)+(\mathrm{W} 2 \times \mathrm{Ty} 2)+(\mathrm{W} 3 \times \mathrm{Ty} 3)\} \\
&=\{(0.425925926 \times 100.455114)+(0.305555556 \times \\
&100.456394)+(0.268518519+100.454666)\} \\
&= 42.7864375+30.6950093+26.9739381 \\
&= 100.455385
\end{aligned}
$$

Koordinat yang didapatkan dari perhitungan manual adalah 0.91997176, 100.455385. Jika dibandingkan antara perhitungan manual dengan perhitungan oleh program pada Tabel 4.6 terdapat sedikit perbedaan hasil. Hal ini dikarenakan oleh adanya beberapa angka dibelakang koma yang tidak diproses oleh program. 


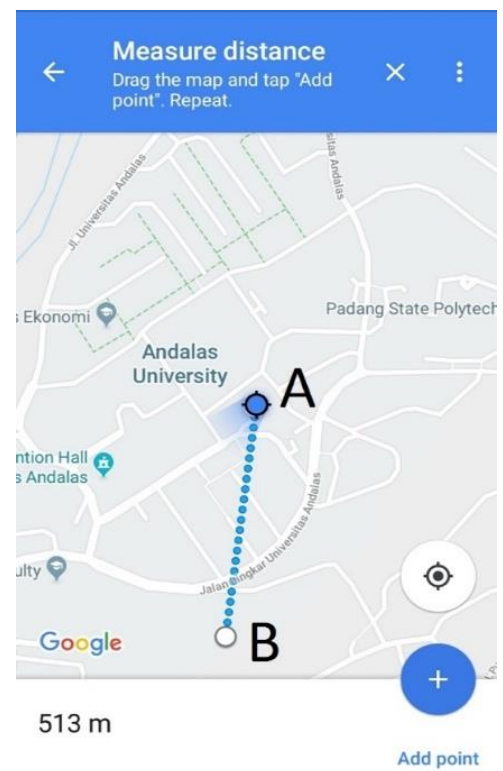

Gambar 9 Tampilan pada Google Map

Dari Gambar 9 dapat dijelaskan bahawa:

A : posisi sebenarnya B : posisi modul GSM SIM 8001 (posisi alat) Gambar 9 merupakan tampilan posisi modul GSM SIM 8001 dan posisi sebenarnya pada google map. Dapat dilihat bahwa terdapat jarak antara titik A dan B. Hal tersebut dikarenakan gedung dan pepohonan yang mengganggu kekuatan sinyal dari BTS ke modul GSM SIM 8001.Jadi, secara keseluruhan ini dikatakan berhasil berhasil dengan persentase keberhasilan $80 \%$. Dimana, terdapat dua buah data error dan rata-rata jarak error adalah 455.875 meter.

\section{KESIMPULAN}

Berdasarkan perancangan, pangamatan, dan pengujian yang telah dilakukan dapat diambil kesimpulan sebagai berikut :

1. Posisi artefak dapat dikirim melalui SMS dan dapat dilihat pada perangkat smartphone dengan catatan bahwa terdapat selish jarak rata-rata antara posisi Modul GSM SIM 8001 dan posisi sebenarnya 455.87 meter.

2. Sistem mobile tracking mampu melacak artefak pada museum dengan penggunaan sistem BTS dengan persentase keberhasilan $80 \%$.

\section{SARAN}

Mengingat masih banyaknya kekurangan dalam penelitian ini, maka perlu ditambahkan beberapa saran diantaranya:

1. Pada penelitian selanjutnya diharapkan agar alat mendapatkan data latitude dan longitude secara otomatis tanpa melakukan hardcode.
2. Pada penilitian selanjutnya diharapkan dapat mengimplementasikan dengan metode Path Loss untuk memperhitungkan gangguan yang mempengaruhi kekuatan sinyal.

3. Diharapkan alat kedepannya mampu menampilkan arah di layar smartphone dan mengirim data secara realtime kepada pengguna.

\section{DAFTAR PUSTAKA}

[1] Atmojo, Junus. 2016. Sejarah Museum dan Pengelolaannya. http://www.kemenpar.go.id/. Diakses tanggal 10 April 2018, Pukul 13.22 WIB.

[2] Matitaputy. 2015. Pentingnya Museum Bagi Pelestarian Warisan Budaya Dalam Pembangunan. https://www.merdeka.com. Diakses tanggal 10 April 2018, Pukul 13.55 WIB.

[3] Direktorat Museum. 2007. Pengelolaan Koleksi Museum. Jakarta : Departemen Kebudayaan dan Wisata.

[4] Mex, Indra. 2017. IT General : Penjelasan Tentang BTS (Base Transceiver Station) Dan Jenis-Jenisnya. Jakarta: Balai Pustaka.

[5] Andesta, D., \& Ferdian, R. (2018, September 29). Sistem Keamanan Sepeda Motor Berbasis Mikrokontroler dan Modul GSM. Journal of Information Technology and Computer Engineering,2(02), 51-63.

[6] Masrura, I., \& Rahmadya, B. (2018, March 29). Indoor Positioning System (IPS) Berdasarkan Kekuatan Received Signal Strength Indicator (RSSI). Journal of Information Technology and Computer Engineering, 2(01), 27-33.

[7] Purnama, Dadan. 2017. Cara Melacak Posisi dari Nomor Handphone. Bandung : CV Naladana.

[8] Neilson, 2013. Mobile Network Geolocation: Obtaining the Cell IDs \& the Signal Strength of Surrounding Towers From a GSM Modem \& Triangulating Device Location. New York: Cambridge University press.

[9] Pantry, Agi Rezka. 2016. Aplikasi Positioning Cell Id Perangkat Machine To Machine (M2m) Pt. Xl Axiata, Tbk Berbasis Website. Bandar Lampung: Fakultas Teknik Universitas Lampung.

[10] Purnama, Rian. 2016. Tutorial Arduino Mengakses Modul GSM SIM800L. Yogyakarta : Rineka Cipta.

[11] Yendri, D., \& Putri, R. (2018, March 29). Sistem Pengontrolan Dan Keamanan Rumah Pintar (Smart Home) Berbasis Android. Journal of Information Technology and Computer Engineering, 2(01), 1-6.

[12] Artha, O., Rahmadya, B., \& Putri, R. (2018, September 29). Sistem Peringatan Dini Bencana Longsor Menggunakan Sensor Accelerometer dan Sensor Kelembabapan Tanah Berbasis Android. Journal of Information Technology and Computer Engineering, 2(02), 64-70.

[13] Husna, T., Ichwana, D., \& Kasoep, W. (2018, September 29). Sistem Pengatur Irigasi Sawah Menggunakan Metode Irigasi Alternate Wetting and Drying Berbasis Teknologi Internet of Things. Journal of Information Technology and Computer Engineering, 2(02), 92-100. 